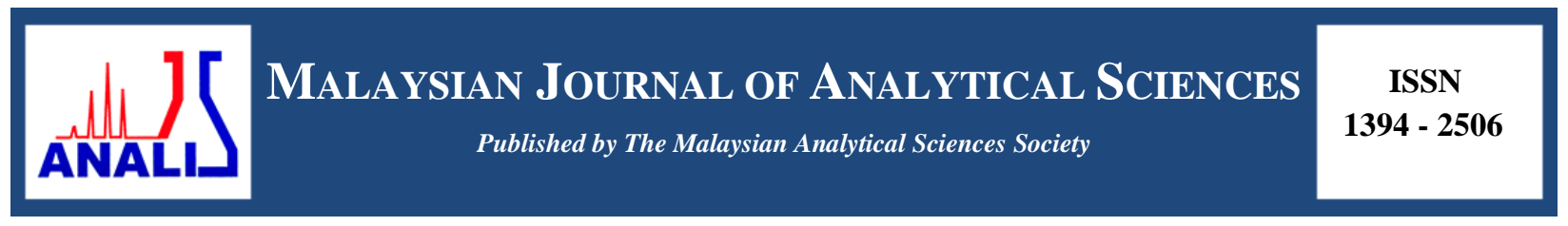

\title{
RARE EARTH ELEMENTS IN SEDIMENT CORES OBTAINED FROM THE PORTS OF TANJUNG PELEPAS AND SEDILI, JOHOR AS POLLUTION INDICATORS
}

\author{
(Unsur Nadir Bumi dalam Teras Sedimen Diperolehi dari Pelabuhan Tanjung Pelepas dan \\ Sedili, Johor Sebagai Penunjuk Pencemaran) \\ Wai Seong Koh and Che Abd Rahim Mohamed* \\ Faculty of Science and Technology, \\ Universiti Kebangsaan Malaysia, 43600 UKM Bangi, Selangor, Malaysia \\ *Corresponding author: carmohd@ukm.edu.my
}

Received: 23 February 2019; Accepted: 12 May 2019

\begin{abstract}
Sediment core samples obtained from the Port of Sedili and Tanjung Pelepas, Johor were slice into layers with intervals of $3 \mathrm{~cm}$ to estimate the contamination levels of rare earth elements at harbour areas. An analysis of rare earth elements (REEs) including $\mathrm{La}, \mathrm{Ce}, \mathrm{Pr}, \mathrm{Nd}, \mathrm{Sm}, \mathrm{Eu}, \mathrm{Gd}, \mathrm{Tb}, \mathrm{Dy}, \mathrm{Ho}, \mathrm{Er}, \mathrm{Tm}, \mathrm{Yb}$ and Lu were conducted using the Inductively Couple Plasma Mass Spectrometry. The measured concentration of REEs normalized with $\mathrm{Fe}$ as an enrichment factors signal. A positive value ratio of $\mathrm{Ce} / \mathrm{Ce}^{*}$ anomalies $(1.10$ - 1.18) was shown at the Port of Sedili whereas at the Port of Tanjung Pelepas showed negative Ce/Ce* anomaly values $(0.87-0.96)$. However, both stations showed weak positive Eu/Eu* anomaly values of $0.76-0.84$ (Port of Sedili) and 0.96 - 1.0 (Port of Tanjung Pelepas). Fractionation index was also using to define the relative behaviour of LREEs to HREEs by the ratio of $\mathrm{La} / \mathrm{Yb}_{\mathrm{n}}$. The results of this study support the proposition to use REEs as an indicator of pollution.
\end{abstract}

Keywords: rare earth elements, core sediment, harbour, pollution indicator, value ratio

\section{Abstrak}

Sampel diperolehi di pelabuhan Sedili dan Tanjung Pelepas, Johor dipotong setiap lapisan $3 \mathrm{~cm}$ untuk anggaran tahap pencemaran unsur nadir bumi di kawasan pelabuhan. Analisis unsur nadir bumi (REEs) iaitu $\mathrm{La}, \mathrm{Ce}, \mathrm{Pr}, \mathrm{Nd}, \mathrm{Sm}, \mathrm{Eu}, \mathrm{Gd}, \mathrm{Tb}$, Dy, Ho, Er, Tm, Yb dan Lu dilakukan dengan Induktif Pasangan Plasma Mass Spektrometri. Kepekatan REEs yang diperolehi akan dinormalkan dengan Fe sebagai faktor penunjuk perkayaan. Nilai nisbah $\mathrm{Ce} / \mathrm{Ce} *$ anamoli $(1.10-1.18)$ adalah positif diperolehi di Pelabuhan Sedili manakala negatif Ce/Ce* anamoli (0.87 - 0.96) di Pelabuhan Tanjung Pelepas. Walaubagaimanapun, kedua-dua stesen menunjukkan nilai positif lemah Eu/Eu* anamoli iaitu 0.76 - 0.84 (Perlabuhan Sedili) dan 0.96 - 1.0 (Perlabuhan Tanjung Pelepas). Indek pecahan juga digunakan untuk mengenalpasti tingkahlaku LREEs hingga HREEs melalui nisbah La/Ybn dan keputusan mendapati menyokong penggunaan REEs sebagai penunjuk pencemaran.

Kata kunci: unsur nadir bumi, teras sedimen, pelabuhan, penunjuk pencemaran, nilai nisbah

\section{Introduction}

REEs are unique metal elements that have similar chemical and physical properties. REEs have low solubility and are not easily transferred during geological processes such as weathering, erosion and transportation due to similarities in electron configurations [1-3]. Hence, REEs have been used extensively to trace the natural processes that happen in the marine environment and are also used as indicators to trace anthropogenic disturbances in marine 
environments [4-9]. The accumulation of light rare earth elements (LREE), enriched by industrial processes such as petroleum catalytic cracking can yield anomaly REE concentrations in river and marine sediments [9].

Concentration levels of REEs in Malaysian habour sediments are not well published by national or international scientists. In order to establish information on Malaysian harbour sediments, we chose two habours at Tanjung Pelepas and Sedili, with the objective of studying the distribution of REE concentrations in sediment cores.

\section{Materials and Methods}

Sediment core samples of about $70 \mathrm{~cm}$ in length from Tanjung Pelepas (Station 1) and Sedili (Station 2) ports were collected with a gravity corer and sliced at $3 \mathrm{~cm}$ intervals. The coordinates of the sampling location (Figure 1) for

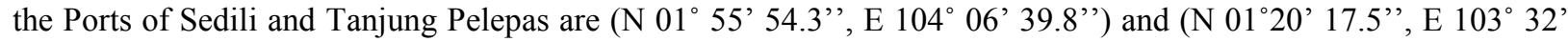
$\left.46.4^{\prime \prime}\right)$, respectively. Sediment samples were dried in an oven at $60^{\circ} \mathrm{C}$ until constant weight before being crushed into homogenized powder using a mortar and pestle, and then sieve through $63 \mu \mathrm{m}$ diameter. About $0.5 \mathrm{~g}$ of dried sample was digested in a mixture of $\mathrm{HClO}_{4}: \mathrm{HNO}_{3}(1: 5 \mathrm{v} / \mathrm{v})$ for 2 hours. An amount $10 \mathrm{~mL}$ of hydrofluoric acid and $2 \mathrm{ml}$ of hydrogen peroxide were then added and further digested to get a paste. The digested samples were dissolved in $2 \% \mathrm{HNO}_{3}$ up to $30 \mathrm{~mL}$ [10]. Similarly, blank and standard reference material (SRM) samples were prepared following the same procedures to verify our analyses. Concentration levels of REE in the samples were determined using calibrated ICP-MS (Model Perkin-Elmer Elan 9000).

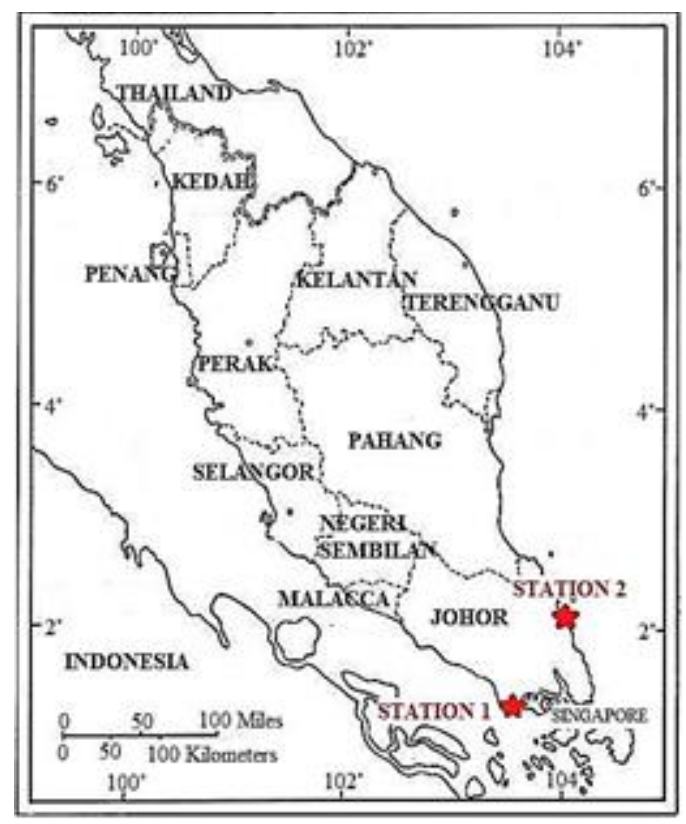

Figure 1. Sampling stations in the east and west coast Peninsular of Malaysia

\section{Results and Discussion}

Post-Archean Australian Shale (PAAS) composition was used to normalize REEs in the study area. PAAS normalized REE patterns in this study can be classified into 2 types. Figure 2a shows relatively flat PAAS normalized REEs whereas Figure $2 b$ shows the enrichment of LREE. The enrichment of LREE reflects the intense silicate weathering of crustal materials and a resultant increase in LREEs in the detrital. This also suggests that its source is from the landmass [11,12]. Generally, REE concentrations at the Port of Sedili is higher than that at the Port of Tanjung Pelepas (Figure 3). Based on the results listed in Table 1, both stations show that LREE is more abundant than HREE. The REEs uptake sequence is LREE > HREE, and REE concentrations show a decreasing 
trend with the increase of depth. Organism behaviors such as bioturbation might increase the concentration of metals in the surface sediment $[6,13,14]$.

Anthropogenic activity is a factor that raises the loading of metals into the environment [15]. Lanthanum (La) and ytterbium $(\mathrm{Yb})$ were chosen as representatives for LREE and HREE. The enrichment factor $(\mathrm{EF})>2.0$ suggest that there are anthropogenic sources, whereas EF $<2.0$ is of natural origin. The EF values for both stations are less than 1 and there is no significant enrichment of REEs (Fig. 4).
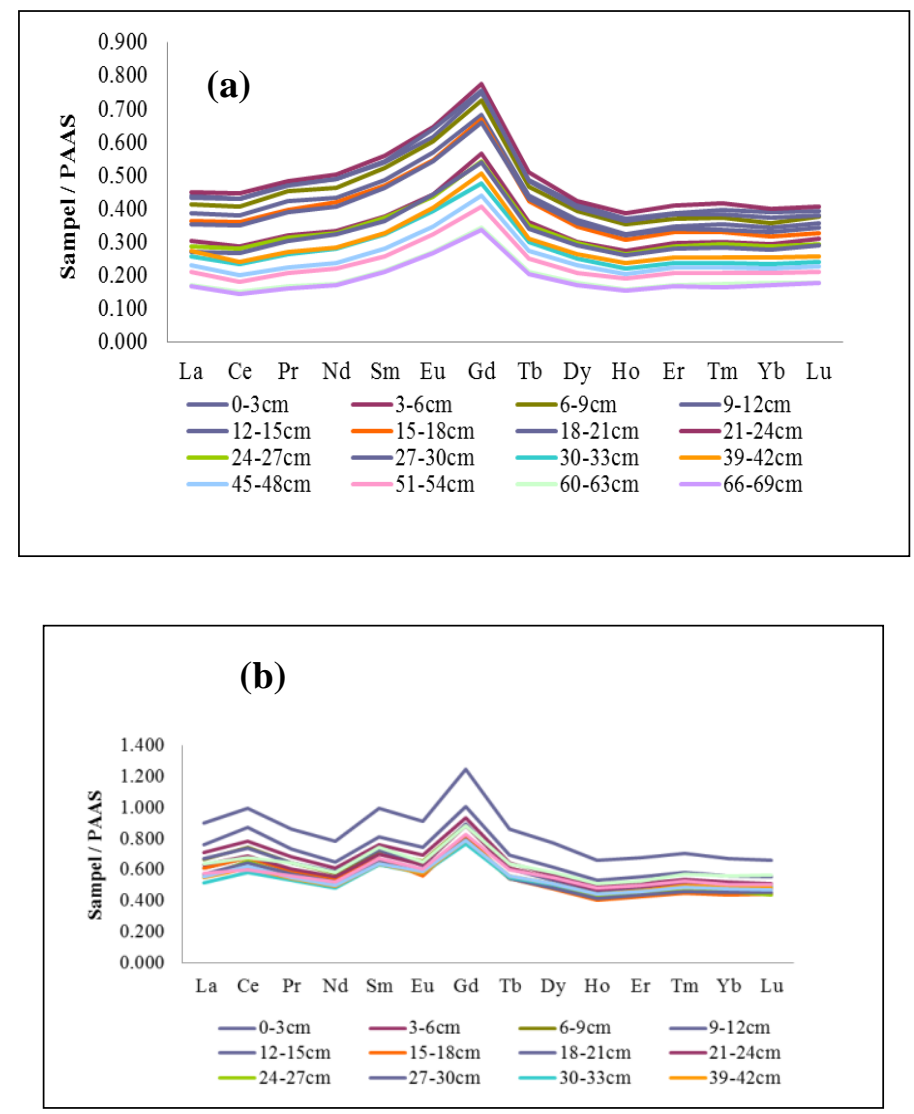

Figure 2. The PAAS normalized REE Distribution Pattern at study station (a) Tanjung Pelepas Port and (b) Selidi Port 
Wai \& Che Ab Rahim: RARE EARTH ELEMENTS IN SEDIMENT CORES OBTAINED FROM THE PORTS OF TANJUNG PELEPAS AND SEDILI, JOHOR AS POLLUTION INDICATORS

Table 1. The Distribution of $\sum$ LREE, $\sum$ HREE, $\sum$ (LREE/HREE), $(\mathrm{La} / \mathrm{Yb})_{\mathrm{n}}, \mathrm{Ce}^{*}$ and $\mathrm{Eu}^{*}$ at the Ports of Tanjung Pelepas and Sedili

\begin{tabular}{llcccccc}
\hline $\begin{array}{l}\text { Depth } \\
(\mathbf{c m})\end{array}$ & Location & $\sum$ LREE & $\sum$ HREE & $\sum$ (LREE/HERE) & $(\mathbf{L a} / \mathbf{Y b})_{\mathbf{n}}$ & $\mathbf{C e}^{*}$ & $\mathbf{E u}^{*}$ \\
\hline $\mathbf{0 - 3}$ & & & & & & & \\
& TPP & 74.98 & 9.45 & 7.93 & 1.13 & 0.94 & 0.97 \\
& SDL & 131.41 & 13.15 & 9.99 & 1.36 & 1.17 & 0.83 \\
$\mathbf{3 - 6}$ & TPP & 77.30 & 9.78 & 7.91 & 1.13 & 0.96 & 0.98 \\
& SDL & 120.46 & 12.16 & 9.91 & 1.37 & 1.13 & 0.82 \\
$\mathbf{6 - 9}$ & TPP & 70.89 & 9.04 & 7.84 & 1.16 & 0.94 & 0.98 \\
& SDL & 113.77 & 11.60 & 9.81 & 1.35 & 1.14 & 0.82 \\
$\mathbf{9 - 1 2}$ & TPP & 74.81 & 9.37 & 7.98 & 1.16 & 0.95 & 1.00 \\
& SDL & 113.67 & 11.49 & 9.89 & 1.36 & 1.12 & 0.78 \\
$\mathbf{1 2 - 1 5}$ & TPP & 66.45 & 8.50 & 7.82 & 1.13 & 0.94 & 0.99 \\
& SDL & 103.63 & 10.40 & 9.86 & 1.38 & 1.13 & 0.80 \\
$\mathbf{1 5 - 1 8}$ & TPP & 62.91 & 8.15 & 7.72 & 1.15 & 0.94 & 0.98 \\
& SDL & 104.39 & 10.35 & 10.09 & 1.40 & 1.12 & 0.76 \\
$\mathbf{1 8 - 2 1}$ & TPP & 61.45 & 8.23 & 7.46 & 1.07 & 0.94 & 0.99 \\
& SDL & 152.96 & 16.20 & 9.44 & 1.34 & 1.13 & 0.82 \\
$\mathbf{2 1 - 2 4}$ & TPP & 50.89 & 7.06 & 7.21 & 1.04 & 0.92 & 0.96 \\
& SDL & 106.85 & 11.53 & 9.26 & 1.31 & 1.11 & 0.80 \\
$\mathbf{2 4 - 2 7}$ & TPP & 49.29 & 6.86 & 7.18 & 1.00 & 0.93 & 0.97 \\
& SDL & 98.73 & 10.43 & 9.46 & 1.21 & 1.18 & 0.84 \\
$\mathbf{6 6 - 6 9}$ & TPP & 26.28 & 4.12 & 6.38 & 0.98 & 0.87 & 1.00 \\
& SDL & - & - & - & - & - & - \\
\hline $\mathbf{6 0 - 6 3}$ & TPP & 47.44 & 6.77 & 7.01 & 0.98 & 0.93 & 1.00 \\
& SDL & 99.41 & 10.37 & 9.59 & 1.26 & 1.13 & 0.81 \\
$\mathbf{3 0 - 3 3}$ & TPP & 42.01 & 5.86 & 7.17 & 1.09 & 0.90 & 1.00 \\
& SDL & 90.59 & 10.60 & 8.55 & 1.06 & 1.11 & 0.83 \\
$\mathbf{3 9 - 4 2}$ & TPP & 43.64 & 6.21 & 7.02 & 1.09 & 0.88 & 0.99 \\
& SDL & 94.40 & 10.73 & 8.80 & 1.12 & 1.12 & 0.82 \\
& TPP & 36.50 & 5.42 & 6.74 & 1.05 & 0.89 & 0.99 \\
& SDL & 95.67 & 10.67 & 8.96 & 1.16 & 1.13 & 0.83 \\
& TPP & 33.40 & 4.98 & 6.70 & 1.02 & 0.87 & 0.99 \\
& SDL & 95.81 & 11.35 & 8.44 & 1.14 & 1.05 & 0.81 \\
& TPP & 27.29 & 4.22 & 6.47 & 0.97 & 0.90 & 1.00 \\
& & & & & TPP & 0.92 & 0.99 \\
& & 107.84 & 12.18 & 8.86 & 1.14 & 1.06 & 0.80 \\
& & & & & &
\end{tabular}

(*) normalized with the Post Achaean Australian Shale (PAAS) 


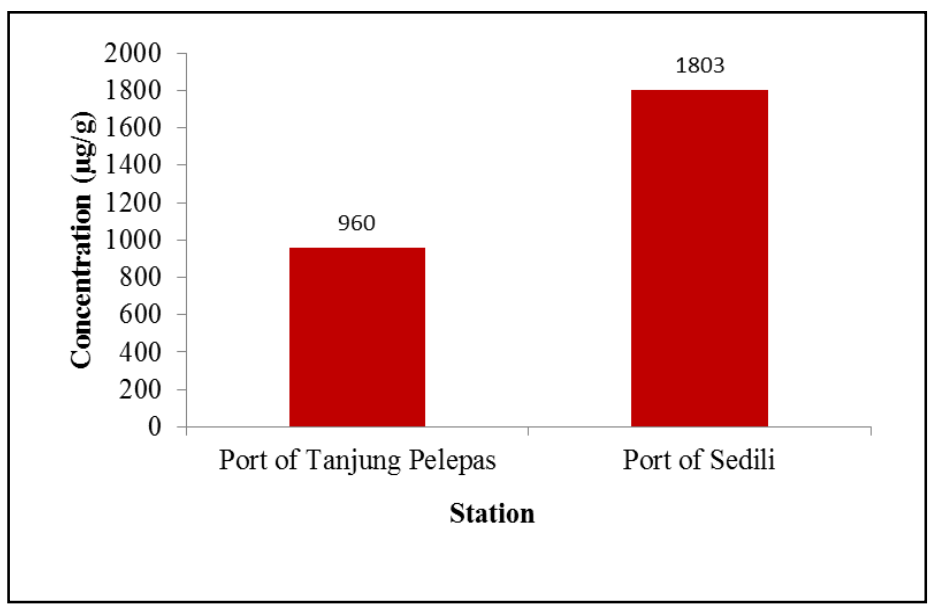

Figure 3. Total concentration of REE for Port of Tanjung Pelepas and Port of Sedili

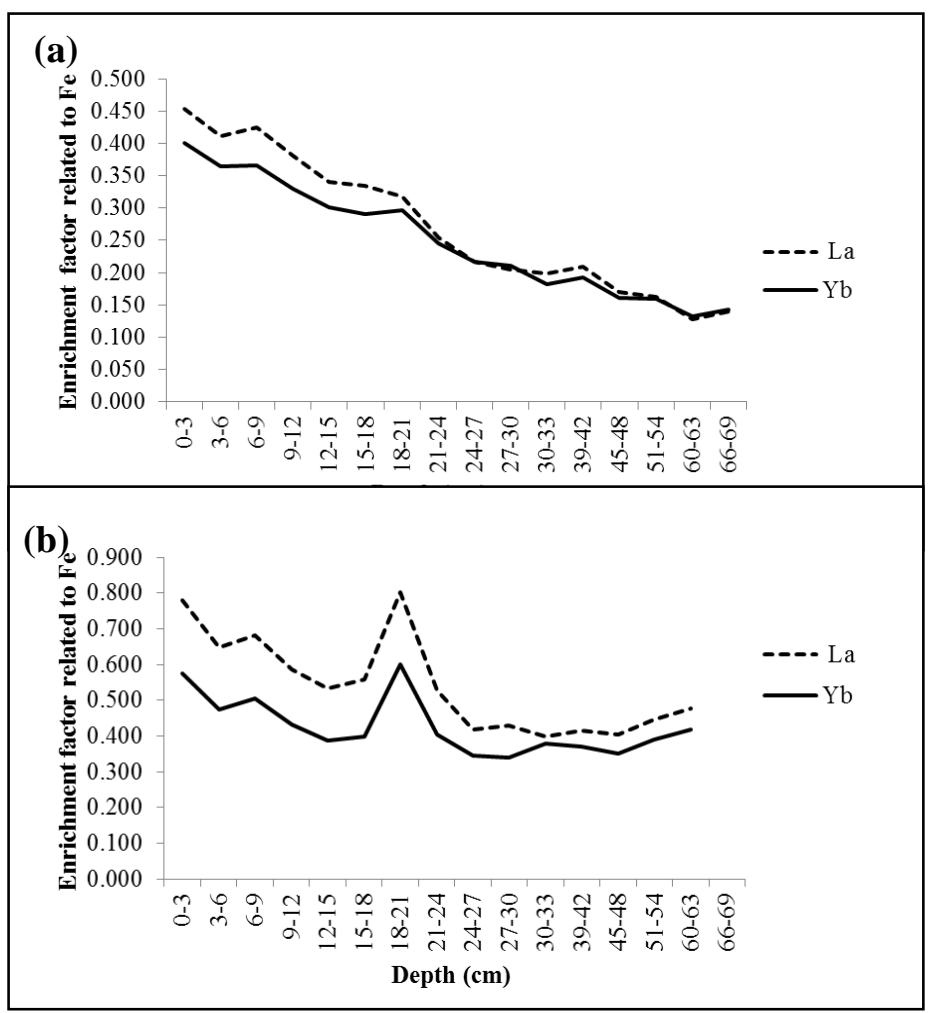

Figure 4. Iron normalized enrichment factor for $\mathrm{La}$ as a function of depth at each sampling station (a) Tanjung Pelepas Port and (b) Selidi Port

The Ce element occurs more abundant in oceanic ferromanganese compared to seawater. Marine manganese nodules have positive $\mathrm{Ce}^{*}$ anomalies due to Cerium easy hydrolyses and co-precipitates with manganese [3]. A negative $\mathrm{Ce}^{*}$ anomaly $(<1)$ shows that the environment is oxic, the reduction process has occurred and the dissolution of insoluble Ce (IV) is reduced to soluble Ce (III) [16]. Liu and Cao [17] suggests that high biogenic and 
chemical depositions will have a negative Ce* anomaly. Positive $\mathrm{Ce} / \mathrm{Ce}^{*}$ anomalies $(1.10-1.18)$ result in Port of Sedili whereas Tanjung Pelepas showed negative $\mathrm{Ce} / \mathrm{Ce}^{*}$ anomalies $(0.87-0.96)$. Negative $\mathrm{Ce}^{*}$ anomalies in the Port of Tanjung Pelepas suggest high biological activity occurs in the study area. Both stations showed weak positive Eu/Eu* anomaly values; $0.76-0.84$ at the Port of Sedili and $0.96-1.0$ at the Port of Tanjung Pelepas. Rudnick [18] suggested that positive Eu* anomalies may be due to the input of hydrothermal vents, aeolian or lithogenic sources. Hydrothermal vents are absent in Malaysian waters, thus the positive $\mathrm{Eu}^{*}$ anomalies at both stations may have resulted from aeolian or lithogenic sources. A high ratio of La/Ybn indicates a high erosion rate [19]. The ratio of $\mathrm{La} / \mathrm{Ybn}$ at the Ports of Tanjung Pelepas and Sedili varied from 0.97 to 1.16 and 1.06 to 1.40 respectively, thus the erosion rate is higher at Port of Sedili compared to the Port of Tanjung Pelepas.

\section{Conclusion}

REEs elements are suitable for use as pollution indicators due to its unique characteristics. The concentration of REEs at the Port of Sedili was higher compared to that at the Port of Tanjung Pelepas. There is no significant enrichment of REEs at both stations. The negative $\mathrm{Ce} / \mathrm{Ce}^{*}$ anomaly value shows that the Port of Tanjung Pelepas had an oxic environment.

\section{Acknowledgement}

The authors would like to thanks the laboratory and individuals for their help during this research and we are grateful for the financial support from the Science Fund Grant No 04-01-02-SF0801 and KPT P(5) 400-7/2/294(65)UPM/700-3/1/JSPS. Finally, many thanks to the laboratory staff of the School of Environmental and Natural Resource Sciences for their technical supports.

\section{References}

1. Kimoto, A., Nearing, M. A., Zhang, X. C. and Powell D. M. (2006). Applicability of rare earth elemenoxides as a sediment tracer for coarse-textured soils. Catena, 65(3): 214-221.

2. Shynu, R., Rao, V. P., Kessarkar, P. M. and Rao, T. G. (2011). Rare earth elements in suspended and bottom sediments of the Mandovi estuary, central west coast of India: Influence of mining. Estuarine, Coastal and Shelf Science, 94(4): 355-368.

3. Zhihua, C., Aiguo, G., Yanguang, L., Haiqing, S., Xuefa, S. and Zuosheng, Y. (2001). REE geochemistry of surface sediments in the Chukchi Sea. Science in China Series D: Earth Sciences, 46(6): 603-611.

4. Åström, M. (2001). Abundance and fractionation patterns of rare earth elements in streams affected by acid sulphate soils. Chemical Geology, 175(3): 249-258.

5. Borrego, J., López-González, N., Carro, B. and Lozano-Soria, O. (2004). Origin of the anomalies in light and middle REE in sediments of an estuary affected by phosphogypsum wastes (south-western Spain). Marine Pollution Bulletin, 49(11): 1045-1053.

6. Davranche, M., Pourret, O., Gruau, G., Dia, A. and Le Coz-Bouhnik, M. (2005). Adsorption of REE(III)humate complexes onto $\mathrm{MnO}_{2}$ : Experimental evidence for cerium anomaly and lanthanide tetrad effect suppression. Geochimica et Cosmochimica Acta, 69(20): 4825-4835.

7. Elderfield, H. and Sholkovitz, E. T. (1987), Rare earth elements in the pore waters of reducing nearshore sediments. Earth and Planetary Science Letters, 82(3): 280-288.

8. Haley, B. A., Klinkhammer, G. P. and Mcmanus, J. (2004). Rare earth elements in pore waters of marine sediments. Geochimica et Cosmochimica Acta, 68(6): 1265-1279.

9. Olmez, I., Sholkovitz, E. R., Hermann, D. and Eganhouse, R. P. (1991). Rare earth elements in sediments of southern California: A new anthropogenic indicator. Environmental Science Techonology, 25(2): 310-316.

10. Mohamed, C. A. R, Narita, H., Harada, K. and Tsunogai, S. (1996). Sedimentation of natural radionuclides on the seabed across the northern Japan Trench. Geochemical Journal, 30: 217-229.

11. Ramesh, R., Ramanathan, A. L., Ramesh, S. and Purvaja, V. R. (2000). Distribution of rare earth elements and heavy metals in the surficial sediments of the Himalayan river system. Geochemical Journal, 34(4): 295-319.

12. Yang, W. L., Mao, X. Y. and Dai, X. X. (2001). REE characteristics and environmental significance in core 96-7-1 in Elson Lagoon in the region of Barrow in the Arctic. Chinese Journal of Polar Research, 13(2): 91106. 
13. Peterson, G. S., Ankley, G. T. and Leonard, E. N. (1996). Effect of bioturbation on metal-sulfide oxidation in surficial freshwater sediments. Environmental Toxicology and Chemistry, 15(12): 2147-2155.

14. Bat, L., Sezgin, M. and Sahin, F. (2018). Heavy metal contamination of aquatic resources from Turkish Black Sea waters. Journal of Environmental Protection and Ecology, 19(2): 558-563.

15. Sadiku, M., Baruti, B. and Kelmendi, M. (2017). Presence of heavy metals in water and sediment of rivers Trepca and Sitnica. Journal of Environmental Protection and Ecology, 18(1): 10-21.

16. Liu, Y. G., Miah, M. and Schmitt, R. (1988). Cerium: A chemical tracer for paleo-oceanic redox conditions. Geochimica et Cosmochimica Acta, 52(6): 1361-1371.

17. Liu, Y. and Cao, L. M. (1987). Introduction of elemental geochemistry (in Chinese), Beijing. Geological Publishing House: pp. 81-97.

18. Rudnick, R. L.(1992). Eu anomalies and the lower continental crust. Geochimica et Cosmochimica Acta, 56(3): 963-970.

19. Anawar, H. and Freitas, M. C. (2010) Analysis of major and trace elements by INAA to predict the thousands year old sediment deposition environment in the Meghna river delta. Journal of Radioanalytical and Nuclear Chemistry, 283(2): 347-352. 